\title{
MARKETING ON POLITICS AND PUBLIC LEADERSHIP
}

\author{
Purwanto $^{1^{*}}$, Eddy Madiono Sutanto ${ }^{2}$, Asmara Indahingwati ${ }^{3}$ \\ ${ }^{1}$ Faculty of Economics, W. R. Supratman University, Indonesia \\ ${ }^{2}$ Faculty of Economics, Petra Christian University, Indonesia \\ ${ }^{3}$ Indonesia School of Economic Surabaya, Indonesia \\ *Corresponding author; Email: cakpo3r@gmail.com
}

\begin{abstract}
This study examines the influence of political marketing and political will on public leadership and individual performance. The sample used is the people in Surabaya as many as 265 with a random sampling method. Amos 21 is used to test the indirect effect by using bootstrap test. The result of the research shows that political marketing and political will have a significant influence to the success of gaining public leadership, political marketing and marketing will have no significant effect on performance, and public leadership has a significant effect on performance. For the indirect influence, political marketing and political will on individual performance are mediated by public leadership.
\end{abstract}

Keywords: Political marketing, political will, performance, public leadership.

\section{Introduction}

Public leadership resulted from direct elections has become increasingly interesting topic in recent years, along with the empirical fact that more needs to be known about this phenomenon (Shaughnessy, Treadway, Breland, \& Perrewé, 2017; Lvina, Maher, $\&$ Harris, 2017). One phenomenon in public leadership contestation is the willingness of the individuals in marketing themselves and political skill owned (O'Shaughnessy, 1990, 2006; Henneberg \& O'Shaughnessy, 2007) to convey the promise of program sincerely that shows the word with action. Although the marketing model in politics differs significantly from the marketing model in business, because in the political world it is something mysterious, it nevertheless has substantially the same ultimate goal of providing value and loyalty to the constituents (Butler \& Collins, 1996; Wring, 1997; Henneberg, 2007). Therefore, the political marketing strategy implementation in public leadership contestation becomes very relevant (O'Cass, 2001; O'Shaughnessy, 2006; Kotler \& Zaltman, 1971).

Empirical facts on the phenomenon have triggered an investigation of public leadership and behavioral consequences and effectiveness of management to the organization (eg, Carson, Tesluk, \& Marrone, 2007; Ensley, Hmieleski, \& Pearce, 2006; Friedrich, Vessey, Schuelke, Ruark, \& Mumford, 2009; Zhang, Waldman, \& Wang, 2012). Some early researchers claimed that the skillful leadership in politics at least is more effective, because it can pack and present perceptions of behavior more ethical, effective and without showing any ulterior motive in society (Ewen $e t$ al., 2014; Harvey, Harris, Kacmar, Buckless, \& Pescosolido, 2014).

Political marketing in democratic parties is analogous to a competitive market, voters or citizens as consumers, and prospective leaders as products or services (Henneberg \& O'Shaughnessy, 2007). The behavior of the Democratic Party and overlapping businesses, eventually led to the culture of consumerism and transactional, causing loyalty to parties and candidates for leadership change (Collins \& Butler, 2003). Politics inherent in most organizations are caused by the informal behavior of members of the organization in order to gain supports as a leader (Mintzberg, 1983). Shaughnessy et al. (2017) argue that the role of the leader is a part of the informal and formal structure, so that this informal role requires both the competence and political ambition to be supported by the subordinates (the people). Therefore, the political will becomes the ultimate requirement owned by a leader. The political will is highly relevant to the process of public leadership because the personality and skills-related traits do not automatically gain power from subordinates (Mintzberg, 1983). Thus, the individual's willingness to engage in the political process must have an appropriate political skill and political marketing.

Political skill as a main requirement in the political will, must be effectively able to understand others at work, and able to influence others to act according to personal and or organizational goals (Ferris et al., 2005; Brouer, Douglas, Treadway, \& Ferris, 2013). Prospective leaders thrive in the space between the formal structure and informal status, so it must risk the reputation capital, as well as the appropriate context to exert the influence of its leadership 
(Treadway, Hochwarter, Kacmar, \& Ferris, 2005; Treadway, Douglas, Ellen, Summers, \& Ferris, 2014; Lvina et al., 2017). Although some previous researchers have discussed the political will and political marketing, a complete understanding about the consideration of political will and political marketing in leadership is still poorly developed, especially the process of ambition, ability and political skill affect the success of leadership (eg, Blickle, Oerder, \& Summers, 2010; Douglas \& Ammeter, 2004; Ammeter, Douglas, Gardner, Hochwarter, \& Ferris, 2002; Treadway et al., 2014). This study combines and extends the literature in developing the political marketing positioning model and the political will towards the performance of public leaders. Based on the previous research, the performance of the work of public leaders is determined by adequate ability: ability to evaluate the dynamics of the organization appropriately, and utilization of the resources as well as the space provided based on his or her leadership status which can improve performance of individuals or organizations (Ammeter et al., 2002; Treadway et al., 2005; Ferris et al., 2007). Specifically, this study aims to investigate the influence of political marketing and political will on public leadership and individual performance.

The constructed hypothesis is that the public leadership mediates the effect of political marketing with the concept of the marketing mix and the political will on the performance of the individual. If the prospective leaders have the power to sell and political skill, the individual's performance as a public leader will be accepted by the organization (government). In the next few sections, there are some reviews on previous researches on political marketing, political will and individual performance. Then it is followed by the description of the research method, including a description of the measurements to test the hypothesis. After reviewing the results of the study, the conclusion is drawn, including some important implications for leaders, weaknesses, and directions of future researches.

\section{Public Leadership}

Many public sector literatures tend to focus on the political leadership of the great men who become political leaders, and the nature or characteristics of the individual. The public sector leadership literature is focused on the president and also to Congress as demonstrated in the Encyclopedia of Leadership (Raffel, Leisink, \& Middlebrooks, 2004). Public sector leadership is much more specific than leadership generally in organizations and even more expansive than political leadership, as some recent publications reveal. Van Wart and Dicke (2007) suggest several types of public sector leadership, namely organization (neglected and focused), politics and movement (Martin Luther King's role in the civil rights movement). Classical organizational theory consists of formal and informal organizations. Formal organization is as a consciously coordinated system of activities of two or more persons (Barnard, 1938). That is explicitly actuating the subordinate to achieve the same goal in gaining success. The central actors in the organization leadership have certain characteristics that effectively can improve the performance in the organization (Scott, 1961). The concept of public leadership status acts as a product of contestation and political skill, which is reflected in the extent to which they recognize as the leader. Therefore, the individual must be accepted and acknowledged in aggregate by the followers, as leaders exert influences over others (Lord \& Maher, 1991; Phillips \& Lord, 1981).

\section{Political Marketing}

The implementation of practical marketing in politics is a new additional concept, which enters the realm of social and nonprofit marketing with various contributions (Mauser, 1983; Newman, 2002; Farrell \& Wortmann, 1987; Reid, 1988; Harrop, 1990; O'Shaughnessy, 1990; Smith \& Saunders, 1990). It introduces the topic and analysis of in-depth marketing instruments, although it does not state specifically as a theory. However, researches on political marketing are rapidly gaining momentum, as driven primarily by the development of dynamic marketing applications of some political parties and candidates, such as in the election of public sector leaders.

Political marketing as a reference or analysis tool of the party or candidate of leaders to promote competitive ideas can help realize organizational goals and satisfy voter groups in exchange for voter's votes (Wring, 1997). O 'Cass (1996) stipulates that the use of marketing aims to offer the ability of political parties to address various problems and needs of voters through analysis of planning, implementing, and controlling of political campaigns and contestation. Furthermore, O 'Cass (1996) argues that the main purpose of political marketing is political parties and voters making the most appropriate and satisfactory decisions for society. Political marketing is a promise and delivery process or implementation that is "produced jointly" by all involved actors (Henneberg \& O'Shaughnessy, 2007).

The marketing political model used in contestation is through the classical concept of marketing mix consisting of product, price, place and promotion (Niffenegger, 1989). The products in politics are the party platforms, track records and personal characte- 
ristics. Political prices include the economic costs, psychological costs and imagery. Distribution includes the marketing programs and volunteer programs. Promotions include the campaigns containing advertising, publications and vote getter. Thus the success of a leader is influenced by how to apply the marketing mix in the appropriate political marketing. Therefore, the hypothesis formulated as follows:

$H_{l}$ : Political marketing has a significant effect on the success of public leadership.

$\mathrm{H}_{2}$ : Political marketing has a significant effect on performance

\section{Political Will}

Power tends to be viewed as a part of an effective leadership; thus, a motivation for power is often investigated in the context of leadership (Shaughnessy et al., 2017; Lvina et al., 2017). The political skill that must be possessed in the need for power (political will) is associated with individual effectiveness (Blickle et al., 2010), leaders (Douglas \& Ammeter, 2004), teams (Ahearn, Ferris, Hochwarter, Douglas, \& Ammeter, 2004), and subordinates (Brouer et al., 2013). Lacking political skills is seen as a pretext to depose leaders (Laird, Zboja, Martinez, \& Ferris, 2013; Van Velsor \& Leslie, 1995). Most great leaders have highly developed social antennae. They use a complex mix of cognitive and observational skills to recognize what followers are consciously and unconsciously signaling to them (Goffee \& Jones, 2005). For example, some studies show that politically skilled individuals who use branding tactics are rated higher than politically unskilled individuals (Harris, Kacmar, Zivnuska, \& Shaw, 2007; Treadway, Ferris, Duke, Adams, \& Thatcher, 2007; Ferris, Treadway, Brouer, \& Munyon, 2012). The increase in performance value is mediated by the perception of leaders on the capabilities and suitability with the people's expectations (Kolodinsky et al., 2007; Wu, Kwan, Wei, \& Liu, 2013). People who have the need for power with political skills are judged to be more effective (Douglas \& Ammeter, 2004) and have high performing teams (Ahearn et al., 2004) than leaders without skill. A leader's political skill is the most important predictor of managerial performance in addition to self-description, self-efficacy, and emotional intelligence (Robins \& Ferris, 2006). Political will emerges as the strongest predictor of adaptive and proactive capabilities and performance when compared to other predictors including professional experience and intrinsic motivation (García-Chas, Neira- Fontela, \& Varela-Nira, 2015).
A person with a high personal power motive will cultivate a cognitive tendency to exert power and influence others (Kehr, 2004). On the other hand, political will would define leadership behaviors that lead to organizational performance (McClelland, Koestner \& Weinberger, 1989; Lord \& Dinh, 2014). The present study highlights certain contexts (e.g., public leadership of a region), as this may trigger this behavior in individuals with a high motivation for power. Political will is often the theme in studies of organizational politics (Treadway, 2012). The need for power represents the mobilization of energy in the pursuit of political goals (Treadway et al., 2005). Motivation or willingness to engage in political behavior will show the actual political behaviors and their political skills will transform those behaviors into organizational outcomes (Shaughnessy et al., 2017). The present study draws on some previous literatures that examine the need for power (political will) and public leadership as a political behavior to influence performance. Political will constitutes a requirement that shall be possessed by a potential leader in order for individual performance to be realized as the final outcomes expected by subordinates.

The (public) organizational performance is a conceptualization of political will since public leadership with political skills is thought to have greater success in the organization (Brouer et al., 2013; Ferris et al., 2005; Ferris et al., 2007). Previous studies show that the construct of political will and political skill of leaders can influence the levels of performance (Ferris et al., 2005). Furthermore, Ferris et al. (2007) suggest that political will has implications for the self, relevant others, and group or organization. Political behaviors characterize the public leadership with a political will; despite the limited social capital and the lack of support from the political party, in terms of grassroots it has a strong mass base to influence. The need for power (political will) of an individual as a leader will have an effect on subordinates (the people). Therefore, the following hypotheses are formulated:

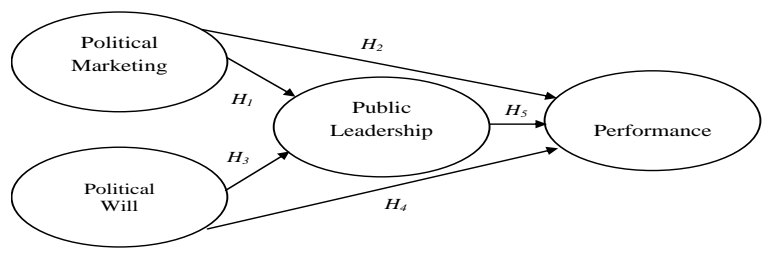

Figure 1. The conceptual model of the proposed framework

$H_{3}$ : Political will (the need for power) has a significant effect on the success of public leadership.

$H_{4}$ : Political will (the need for power) has a significant effect on performance. 
$H_{5}$ : The success of public leadership has a significant effect on individual performance.

The conceptual framework that describes the overall hypothesis is shown in Figure 1.

\section{Research Method}

\section{Samples and Procedures}

The sample of respondents encountered in offices, shopping centers or campuses were taken in Surabaya by using the random sampling technique. Of 300 respondents, a total of 265 (or 88\%) was deemed eligible for analysis. In detail, 160 respondents (or $60.3 \%$ ) were male and 85 or $32.07 \%$ were female and 20 or $7.53 \%$ did not identify their sex and their average age was 32.5 years). With regard to education level $65.0 \%$ of respondents were undergraduate, $20.0 \%$ had a master degree, $10.0 \%$ had a doctoral degree, and $5.0 \%$ did not identify their level of education. Furthermore, $71.5 \%$ of respondents were from Surabaya and $28.5 \%$ from outside Surabaya.

\section{Research Measuring Instrument}

All the scales used in the present study are adapted from the measuring instruments that have been tested and validated by previous researchers. Political marketing is measured by a measurement consisting of product politics, price politics, distribution politics and promotional politics (Niffenegger, 1989; Henneberg \& O'Shaughnessy, 2007; O'Shaughnessy, 2006). The items use a 5 -point scale $(1=$ strongly disagree, $5=$ strongly agree).

The items of subordinate perceptions of the leader's political will (the need for power) are adapted from McClelland (1975), Ferris et al. (2005), Shaughnessy et al. (2017) and Lvina et al. (2017). These include the personal influence (e.g., "It's easy to build good relationships with most people"), the social intelligence (e.g., "He understands people very well"), the behavioral integrity (e.g., "When communicating with others, he is trying to be sincere about what he says and he does"), the networking capability (e.g., "He devotes a lot of time and efforts building networks with others"), and the political skills ("Al- ways be instinctively aware of the right thing to say and to do to influence others").

Public leadership is measured by the political will of aspects of leadership traits (Knoke \& Burt, 1983; Lord \& Dinh, 2014) and representation networks. Some earlier investigators ask respondents to answer a statement addressed to a list of all candidate leaders (e.g., Neubert \& Taggar, 2004; Venkataramani, Richter \& Clarke, 2014; Zhang et al., 2012). Specifically, respondents are asked to nominate their candidate leaders and to put a tick next to the name of individual considered as a suitable leader. However, the present study does not mention the names of candidate regional leaders in order to avoid subjectivity and, coincidentally, there will be an election of Governor and Vice Governor of East Java Province in 2018.

With regard to the performance variables, organizational performance measures similarly to those of other study investigating performance or work performance (i.e., Zhang et al., 2012), covering employee relationships with colleagues and their supervisors, their interactions with other staff and clients, professionalism, and punctuality. The control variables used from the number of collected demographic variables consist of age, gender, and education, which are taken into account in this analysis as age (Sturman, 2003; Waldman \& Avolio, 1986), gender (Eagly \& Karau, 2002), and education (Biernat \& Kobrynowicz, 1997) have shown to have an effect on leadership and/or performance, as found by Waldman and Avolio (1986) that job performance may increase with the age.

\section{Results and Discussions}

\section{Reliability and Construct Validity}

To test the construct validity of each scale, the present study uses the confirmatory construct analysis (CFA) and analyzes the covariance matrix by using the maximum likelihood procedure of Amos 21. The complete results of CFA, including mean, standard deviation, construct reliability, average variance extracted (AVE) and bivariate correlations among each latent factors can be found in Table 1. 
Table 1.

Descriptive Statistic, Inter-Correlations, and Confirmatory Factor Analysis (CFA) Results

\begin{tabular}{|c|c|c|c|c|c|c|c|c|c|c|c|c|}
\hline Variable & $M$ & $S D$ & $\alpha$ & CR & AVE & 1 & 2 & 3 & 4 & 5 & 6 & 7 \\
\hline Age & 4.30 & 0.88 & 0.77 & 0.76 & 0.65 & 0.61 & & & & & & \\
\hline Gender & 5.15 & 1.17 & 0.95 & 0.91 & 0.74 & $-0.21^{* *} *$ & 0.87 & & & & & \\
\hline Education & 5.11 & 1.07 & 0.96 & 0.95 & 0.83 & $-0.23^{* *}$ & $0.77^{* *}$ & 0.92 & & & & \\
\hline Political marketing & 5.74 & 0.93 & 0.94 & 0.94 & 0.75 & $-0.22 * *$ & $0.68 * *$ & $0.75^{*}$ & 0.88 & & & \\
\hline Political will & 5.51 & 1.17 & 0.95 & 0.93 & 0.86 & -0.10 & $0.87^{* *}$ & $0.70^{*}$ & $0.72^{*}$ ** & 0.89 & & \\
\hline Public leadership & 5.17 & 0.92 & 0.91 & 0.91 & 0.69 & -0.14 & $0.25^{* *}$ & $0.18^{*}$ & 0.15 & $0.21^{\text {*k }}$ & 0.84 & \\
\hline Performance & 5.22 & 0.34 & - & - & 0.80 & $-0.15^{*}$ & 0.04 & 0.05 & -0.05 & 0.04 & $0.21^{* *}$ & 0.87 \\
\hline
\end{tabular}

Model fit: $\chi^{2}=2507.11, p<0.01, d f=1.303 ;$ CFI $=0.88 ;$ TLI $=0.87 ;$ RMSEA $=0.08 ;$ SRMR $=0.07$

Note. $N=265 . \uparrow p<0.10{ }^{*} p<0.05$. $* * p<0.01$

The results show that the measurement model corresponds to the data adequately $\left(\chi^{2}=2507.11 ; p\right.$ $<0.01 ; d f=1.303 ; \mathrm{CFI}=0.88 ; \mathrm{TLI}=0.87$; RMSEA $=0.08 ;$ SRMR $=0.07$ ). In addition, items incorporated into the measurement model have construct reliability ranging from 0.78 to 0.98 , indicating that the measuring instrument is very reliable. Furthermore, Churchill, Jr. (1979) suggested that the construct must be tested for its convergent validity and discriminant validity.

The average variance extracted (AVE) for political marketing is 0.88 , political will 0.89 , public leadership 0.84 , and performance 0.87 . All values exceed the recommended level of 0.50 . Thus, the scales of political marketing, political will, public leadership, and performance have a convergent validity since these variables show a greater explanatory power than the error variance (Fornell \& Larcker, 1981).

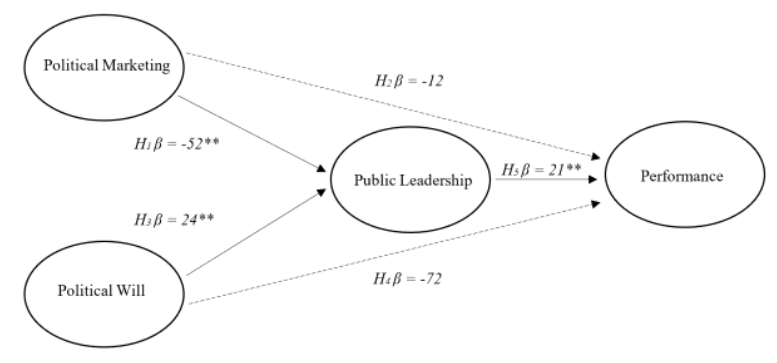

Figure 2. Hypothesis test result

\section{Hypothesis Testing}

The path analysis is conceptualized on the model using AMOS 21. The results of the structural model can be seen in Table 2 and the result of the hypothesis testing can be seen in Figure 2.

Overall, the model shows a fit with the data $\left(\chi^{2}=\right.$ $3.53, p=0.75, d f=7$; CFI $=1.01$; TLI $=1.03$; RMSEA $=0.00$; SRMR $=0.03$ ); as can be seen from Table 2. Political marketing has a significant effect on public leadership $(\beta=0.52, p<0.01)$ and political marketing has a significant effect on public leadership $(\beta=0.24, p<0.01)$, and public leadership has a significant effect on performance $(\beta=0.21, p<0.01)$. Thus, the results support $H_{1}, H_{3}$, and $H_{5}$, while $H_{2}$ and $\mathrm{H}_{4}$ are not supported.

The indirect effect bootstrap test (Preacher \& Hayes, 2008) is used to evaluate hypotheses, between implicit variables in the model, as in Table 3 . The analysis results show that there is a significant direct influence of political marketing of the leader on the performance $(a \times b=0: 13 ; 95 \%$ CI [0:06, 0.21]).

When there is a direct effect of leaders political marketing to the performance of the models, the line was not significant $(\beta=0.04, p=0.55$ ). Simultaneously, the effect of the leader's political marketing on performance is entirely mediated by the success of public leadership. Similarly, a direct influence on the performance of political will is also fully mediated by the success of public leadership $(a \times b=0.17 ; 95 \% \mathrm{CI}$ $[0.02,0.12])$ and $(\beta=0.05, p=0.54)$. Thus, support was found for Hypothesis 1 and 3.

The indirect effect of political marketing on performance is not significant $(a \times b=-0.01 ; 95 \%$ CI $[0.04,0.02] \beta=0.12^{* *}$ and the indirect effect of political will on performance is also insignificant, ( $a \times b=$ $-0.02 ; 95 \%$ CI $[-0.02,0.11] \beta=0.72 * *)$. Hence Hypothesis 2 and Hypothesis 4 are not supported. The direct effect of public leadership to performance is very significant $(a \times b=0.21 ; 95 \%$ CI $[0.07,0.20] \beta=0.01$ $(p=0.51)$. This means that someone who has high political marketing and political will and is recognized as a leader also achieves high performance values. Thus, support is found for Hypothesis 5.

The results of the analysis indicate that someone who has high political marketing and political will (i.e., high power motivation) is more likely to be recognized as a leader, and the performance of a leader is found to depend on political marketing and political skills. Thus, the present study extends the literature on marketing in politics to gain public leadership legiti- 
Table 2

Structural Model Result

\begin{tabular}{lcc}
\hline Paths & $\boldsymbol{B}$ & $\boldsymbol{R}^{2}$ \\
\hline Political Marketing $\rightarrow$ Public Leadership & $0.52^{* *}$ & $69.5 \%$ \\
Political Marketing $\rightarrow$ Performance & -0.03 & \\
Political Will $\rightarrow$ Public Leadership & $0.23 * *$ & $77.5 \%$ \\
Political Will $\rightarrow$ Performance & -0.07 & \\
Public Leadership $\rightarrow$ Performance & $0.21^{* *}$ & $7.5 \%$ \\
Model fit: $\chi^{2}=3.53, p=0.75, d f=7 ;$ CFI $=1.01 ;$ TLI $=1.03 ;$ RMSEA $=0.00 ;$ SRMR $=0.03$ & \\
\hline Note. $N=265 . \dagger p<0.10 . * p<0.05 . * * p<0.01$. & &
\end{tabular}

Table 3.

Bootstrap Test of the Standardized Indirect Effects

\begin{tabular}{lccc}
\hline & $\boldsymbol{a} \boldsymbol{x} \boldsymbol{b}$ & $\mathbf{9 5 \%}$ CI & $\boldsymbol{\beta}_{\text {direct path }}$ \\
\hline Political marketing $\rightarrow$ public leadership $\rightarrow$ performance & $0.13^{* *}$ & {$[0.06,0.21]$} & $0.04(p=0.55)$ \\
Political marketing $\rightarrow$ performance & -0.01 & {$[-0.04,0.02]$} & $0.12^{* *}$ \\
Political will $\rightarrow$ public leadership $\rightarrow$ performance & $0.17 * *$ & {$[0.02,0.12]$} & $0.05(p=0.54)$ \\
Political will $\rightarrow$ performance & -0.02 & {$[-0.02,0.11]$} & $0.72 * *$ \\
Public leadership $\rightarrow$ performance & $0.21^{* *}$ & {$[0.07,0.20]$} & $0.01(p=0.51)$ \\
\hline
\end{tabular}

Note. $N=265$. CI = confidence interval; Analyses based on 1,000 replications (Preacher \& Hayes, 2008). The $\beta_{\text {direct path }}$ represents the standardized parameter estimate of the $X \rightarrow Y$ direct path when included in the structural model. ${ }^{\dagger} p<0.10 .{ }^{*} p$ $<0.05 . * * p<0.01$.

macy by providing empirical evidence of individual differences between those with political skills and political marketing as well. The results showed that individuals with political marketing and political will (i.e., someone who has the power motives) are more likely to be recognized as a potential leader, but recognition by the community as a leader is not associated with the level of performance appraisal. This shows that the performance of public leaders depends on the ability to manage the organization (government) obtained through political skill ownership in the political will of a person. Findings of this study indicate that individuals who have a precise political marketing and high political will, to gain public leadership success, cannot be used to judge individual performance in the organization, so there is still a need for further research on the antecedents of performance appraisal of leaders. In other words, the success of public leadership cannot be seen as limited to political marketing and political will alone.

Realizing that the construct of political marketing and political will are contemporary and pragmatic, the results of the analysis are limited to how a potential leader seeks victory in a political contest. In addition, with regard to political marketing and political will associated with the effectiveness of leaders and teams (the performance), the mechanism by which leaders use political marketing and have political will that can lead to effective subordinate functions cannot be measured by using the two constructs (Ahearn et al., 2004; Douglas \& Ammeter, 2004; Treadway et al., 2014). Results also show that those individuals who rightfully use political marketing and are politically skilled are more adept at the branding management and able to disguise their insincere motives (Harris et al., 2007; Treadway et al., 2007, Ferris et al., 2007; Wu et al., 2013), leading their positioning in the public eye to be more acceptable.

Associated with the holistic marketing theory (Kotler, 2003), the results of the present study cannot be fully applied to power politic activities since the application of marketing to practical politics is different from business activities that should be far from politics, and politics is considered very mysterious (Henneberg, 2007). For example, the mix program of political marketing derived from products, promotions, prices and places is strongly influenced by individual track records, and the sincerity shown by potential leaders (Lvina et al., 2017; Henneberg \& O'Shaughnessy, 2007; Niffenegger, 1989).

Coupled with the emergence of transactional culture, marketing practices become running less well as it should do in the business world. Therefore, regardless the political marketing and political skills that should be in line with the words and deeds of leaders, subordinates (the people) will respond to leaders (e.g., to vote and mobilize others) based on their perceived quality of leaders. Furthermore, a potential leader or regional head and perhaps also political parties have to increase their awareness by using a buzzer model in order to familiarize everyone. Thus, the subordinates' perception of the leaders' alignment of words and deeds deserves further investigation. 
Finally, this model further demonstrates that political marketing and political will (motivation) serve as the public leadership to instigate the willingness of the subordinates (people) to achieve certain goals (Shaughnessy et al., 2017; Henneberg \& O'Shaughnessy, 2007). On the contrary, Treadway et al. (2005) focuses on the role of political will as a resource to undertake political behavior; however, to utilize their status to achieve personal gain (i.e., performance) a leader should be provided with adequate political skills. These findings prove that the motivation of power (political will) is a different entity with political marketing, but both are important to gain public leadership, which is expected to run the organization well so that performance measurement can be measured. In addition, this study provides empirical support for the theoretical positioning of political will as a personal resource in gaining a leadership position (Ferris et al., 2007; Ferris et al., 2005).

\section{Conclusions and Implications}

The phenomenon of public leadership that uses the strategy of marketing and political will cannot determine the effectiveness of prospective leaders in improving performance. Meanwhile, Brass (2001) argues that leader effectiveness is less based on leadership traits, but rather on the ability to complete work through others. Individual work performance depends on a match between political skill and the context of public leadership. In short, empirical support for the development of the concept of public leadership strategies found provides a basis for understanding, identification, and success of public leaders in organizations. A prospective congenial leader is using political marketing and skillful in politic and more adept at imaging management and able to disguise the motive was sincere, to sell himself as a prospective leader. Political marketing is not fully applied into the political activities of power, because the application of marketing in different practical politics in business activities should be away from politics and politics is considered very mysterious.

\section{Practical Implications}

The most apparent implication of this research findings is that political will equipped with political skill can be used to influence people's perceptions. Political will and political marketing have an important place in the contestations of public leadership. Some leaders may not be aware of the impact of the unfulfilled promises in their political campaigns, but an aware leader will immediately fulfill his promises.
Political will and political marketing has an important place in public leadership contestation. Some leaders may not realize the impact of the pledge violated in the political campaign, but leaders quickly realized will soon fulfill his promise.

In addition, there are some important practical implications with regard to public leadership, which is the political will would be framed with good political skills that can be built and managed better. Thus, there is an opportunity to help people become more selfaware, conscious of the promises they make, and find out how they intentionally or unintentionally communicate promises and values of leaders. Organizations should ensure that a leader can understand the effect caused by the alignment of words with their deeds on the effectiveness of the organization. Public leaders should also continue to make innovation on packaging design of marketing mix which is more unique so that marketing practices in politics work well.

\section{Limitations of Research}

There is the potential ambiguity with regard to the theoretical conceptualization of public leadership because it can be confused with other concepts such as the private leadership (business) in the formal organization (Barnard, 1938). Furthermore, the generalization of the results of the present study to the formal leadership literature can be influenced by the context in which the research is conducted (Anderson, Spataro, \& Flynn, 2008; Lord \& Dinh, 2014) and operationalized in formal organizational leaders that do not distinguish the public from private sectors. Thus, generalization of the use of leadership concept should be tailored to the existing context, whether in public or private organizations. However, the findings of previous studies support the validity of the results of the present study (Balkundi \& Kilduff, 2005). As previously described, political will together with political skills are not necessarily acceptable to the people. Nevertheless, a truly politically skilled leader will be able to appear genuinely, regardless of whether they are naturally so or not.

\section{Directions of Future Research}

Mintzberg's (1983) discussion of the definition and mechanism of political will show a detailed explanation, in which political will is highly relevant to the process of public leadership since the personality and traits associated with political skill cannot in itself secure a strong position from subordinates. Unfortunately, few studies attempt to implement his thoughts. Similarly, Treadway (2012) considers political will 
necessary to explain how motivation affects the political process within an organization. The conceptual considerations are of particularly concerned to leadership researchers (Osborn, Hunt, \& Jauch, 2002), but public leadership researchers have little to say about these issues. Additionally, the conceptualization of political marketing also cannot be fully used since there is a significant difference in the packaging of the appropriate marketing mix (see Niffenegger, 1989; Henneberg \& O'Shaughnessy, 2007). This gap may trigger the idea to investigate marketing in a more practical political context.

\section{References}

Ahearn, K. K., Ferris, G. R., Hochwarter, W. A., Douglas, C., \& Ammeter, A. P. (2004). Leader political skill and team performance. Journal of Management, 30(3), 309-327.

Ammeter, A. P., Douglas, C., Gardner, W. L., Hochwarter, W. A., \& Ferris, G. R. (2002). Toward a political theory of leadership. Leadership Quarterly, 13(6), 751-796.

Anderson, C., Spataro, S. E., \& Flynn, F. J. (2008). Personality and organizational culture as determinants of influence. Journal of Applied Psychology, 93(3), 702-710.

Balkundi, P. \& Kilduff, M. (2005). The ties that lead: A social network approach to leadership. Leadership Quarterly, 17(4), 419-439.

Barnard, C. I. (1938). The functions of the executive. Cambridge, MA: Harvard University Press.

Biernat, M. \& Kobrynowicz, D. (1997). Gender-and race-based standards of competence: Lower minimum standards but higher ability standards for devalued groups. Journal of Personality and Social Psychology, 72(3), 544-557.

Blickle, G., Oerder, K., \& Summers, J. K. (2010). The impact of political skill on career success of employees' representatives. Journal of Vocational Behavior, 77(3), 383-390.

Brass, D. J. (2001). Social capital and organizational leadership. In S. J. Zaccaro \& R. J. Klimoski (Eds.). The nature of organizational leadership: understanding the performance imperatives confronting today's leaders (pp. 132-152). San Francisco, CA: Jossey-Bass.

Brouer, R. L., Douglas, C., Treadway, D. C., \& Ferris, G. R. (2013). Leader political skill, relationship quality, and leadership effectiveness: A two-study model test and constructive replication. Journal of Leadership \& Organizational Studies, 20 (2), 185-198.
Butler, P. \& Collins, N. (1996). Strategic analysis in political markets. European Journal of Marketing, 30(10/11), 25-36.

Carson, J. B., Tesluk, P. E., \& Marrone, J. A. (2007). Shared leadership in teams: An investigation of antecedent conditions and performance. Academy of Management Journal, 50(5), $1217-$ 1234.

Churchill, Jr. G. A. (1979). A paradigm for developing better measures of marketing constructs. Journal Marketing Research, 16(1), 64-73.

Collins, N. \& Butler, P. (2003). When marketing models clash with democracy. Journal of Public Affairs, 3(1), 52-62.

Douglas, C. \& Ammeter, A. P. (2004). An examination of leader political skill and its effect on ratings of leader effectiveness. The Leadership Quarterly, 15, 537-550.

Eagly, A. H. \& Karau, S. J. (2002). Role congruity theory of prejudice toward female leaders. Psychological Review, 109(3), 573-598.

Ensley, M. D., Hmieleski, K. M., \& Pearce, C. L. (2006). The importance of vertical and shared leadership within new venture top management teams: Implications for the performance of startups. Leadership Quarterly, 17(3), 217-231.

Ewen, C., Wihler, A., Frieder, R. E., Blickle, G., Hogan, R., \& Ferris, G. R. (2014). Leader advancement motive, political skill, leader behavior, and effectiveness: A moderated mediation extension of socioanalytic theory. Human Performance, 27(5), 373-392.

Farrell, D. M. \& Wortmann, M. (1987). Party strategies in the electoral market: Political marketing in West Germany, Britain and Ireland. European Journal of Political Research, 15, 297-318.

Ferris, G. R., Treadway, D. C., Brouer, R. L., \& Munyon, T. P. (2012). Political skill in the organizational sciences. In G. R. Ferris, \& D. C. Treadway, (Eds.), Politics in organizations: Theory and research considerations (pp. 487528, SIOP Frontier Series volume). New York, NY: Routledge.

Ferris, G. R., Treadway, D. C., Kolodinsky, R. W., Hochwarter, W. A., Kacmar, C. J., Douglas, C., $\&$ Frink, D. D. (2005). Development and validation of the political skill inventory. Journal of Management, 31(1), 126-152.

Ferris, G. R., Treadway, D. C., Perrewé, P. L., Brouer, R. L., Douglas, C., \& Lux, S. (2007). Political skill in organizations. Journal of Management, 33(3), 290-320.

Fornell, C. \& Larcker, D. F. (1981). Evaluating structural equation models with unobservable 
variables and measurement error. Journal Marketing Research, 18(1), 39-50.

Friedrich, T. L., Vessey, W. B., Schuelke, M. J., Ruark, G. A., \& Mumford, M. D. (2009). A framework for understanding collective leadership: The selective utilization of leader and team expertise within networks. The Leadership Quarterly, 20(6), 933-958.

García-Chas, R., Neira-Fontela, E., \& Varela-Neira, C. (2015). Comparing the explanatory capacity of three constructs in the prediction of engineers' proficiency, adaptivity, and proactivity. Human Resource Management, 54(4), 689-709.

Goffee, R. \& Jones, G. (2005). Managing authenticity: The paradox of great leadership. Harvard Business Review, 83(12), 87-94.

Harris, K. J., Kacmar, K. M., Zivnuska, S., \& Shaw, J. D. (2007). The impact of political skill on impression management effectiveness. Journal of Applied Psychology, 92(1), 278-285.

Harrop, M. (1990). Political Marketing. Parliamentary Affairs, 43(3), 277-291.

Harvey, P., Harris, K. J., Kacmar, K. M., Buckless, A., \& Pescosolido, A. T. (2014). The impact of political skill on employees' perceptions of ethical leadership. Journal of Leadership \& Organizational Studies, 21(1), 5-16.

Henneberg, S. C. (2007). An epistemological perspective on research in political marketing. Journal of Political Marketing, 6, forthcoming.

Henneberg, S. C. \& O'shaughnessy, N. J. (2007). Theory and concept development in political marketing. Journal of Political Marketing, $6(2 / 3), 5-31$.

Kehr, H. M. (2004). Integrating implicit motives explicit motives and perceived abilities: The compensatory model of work motivation and volition. Academy of Management Review, 29(3), 479-499.

Knoke, D. \& Burt, R. S. (1983). Prominence. In R. S. Burt \& M. J. Minor (Eds.), Applied network analysis (pp. 195-222). Newbury Park, CA: Sage.

Kolodinsky, R. W., Treadway, D. C., \& Ferris, G. R. (2007). Political skill and influence effectiveness: Testing portions of an expanded Ferris and Judge (1991) model. Human Relations, 60(12), 1747-1777.

Kotler, P. (2003). Marketing management, $11^{\text {th }}$ Ed. New Jersey: Person Education, Inc.

Kotler, P. \& Zaltman, G. (1971). Social marketing: An approach to planned social change. Journal of Marketing, 35(3), 3-12.
Laird, M. D., Zboja, J. J., Martinez, A. D., \& Ferris, G. R. (2013). Performance and political skill in personal reputation assessments. Journal of Managerial Psychology, 28(6), 661-676.

Lord, R. G. \& Dinh, J. E. (2014). What have we learned that is critical in understanding leadership perceptions and leader-performance relations? Industrial and Organizational Psychology: Perspectives on Science and Practice, 7 (2), 158-177.

Lord, R. G. \& Maher, K. J. (1991). People and organizations, leadership and information processing: Linking perceptions and performance volume 1. Cambridge, MA: Unwin Hyman.

Lvina, E., Maher, L.P., \& Harris, J.N. (2017). Political skill, trust, and efficacy in teams. Journal of Leadership and Organizational Studies, 24(1), 95105.

Mauser, G. A. (1983) Political Marketing: An approach to campaign strategy. New York, NY, USA: Praeger.

McClelland, D. C. (1975). Power: The inner experience. New York, NY: Irvington.

McClelland, D. C., Koestner, R., \& Weinberger, J. (1989). How do self attributed and implicit motives differ? Psychological Review, 96(4), 690-702.

Mintzberg, H. (1983). Power in and around organizations. Englewood Cliffs, NJ: Prentice Hall.

Neubert, M. J. \& Taggar, S. (2004). Pathways to informal leadership: The moderating role of gender on the relationship of individual differences and team member network centrality to informal leadership emergence. Leadership Quarterly, 15 (2), 175-194.

Newman, B. I. (2002). Editorial: The role of marketing in politics. Journal of Political Marketing, 1 , $1-5$.

Niffenegger, P. B. (1989). Strategis for success from the political marketers. The Journal of Consumer Marketing, 6(1), 45-51.

O'Cass, A. (1996). Political marketing and marketing concept. European Journal of Marketing, 30(10/11), 37-53.

(2001). Political marketing: An investigation of the political marketing concept and political market orientation in Australian politics. European Journal of Marketing, 35(9/10), 1003-1025.

Osborn, R. N., Hunt, J. G., \& Jauch, L. R. (2002). Toward a contextual theory of leadership. Leadership Quarterly, 13(6), 797-837. 
O'Shaughnessy, N. J. (1990). The phenomenon of political marketing. UK: Palgrave Macmillan. (2006). Election 2005: The art and science of political marketing. Journal of Marketing Management, 22, 233-240

Phillips, J. S. \& Lord, R. G. (1981). Causal attributions and perceptions of leadership. Organizational Behavior and Human Performance, 28 (2), 143-163.

Preacher, K. J. \& Hayes, A. F. (2008). Asymptotic and resampling strategies for assessing and comparing indirect effects in multiple mediator models. Behavior Research Methods, 40(3), 879-891.

Raffel, J. A., Leisink, P., \& Middlebrooks, A. E. (2004). Conclusion. In J. A. Raffel, P. Leisink, \& A. E. Middlebrooks (Eds.), Public sector leadership: International challenges and perspectives (pp. 377-388). Chaltenham, UK: Edward Elgar Publishing Limited.

Reid, D. M. (1988). Marketing the political product. European Journal of Marketing, 22(9), 34-47.

Scott, W. G. (1961). Organization theory: An overview and an appraisal. Academy of Management Journal, 4(1), 7-26.

Semadar, A., Robins, G., \& Ferris, G. R. (2006). Comparing the validity of multiple social effectiveness constructs in the prediction of managerial job performance. Journal of Organizational Behavior, 27(4), 443-461.

Shaughnessy, B. A., Treadway, D. C., Breland, J. W., \& Perrewé, P. L. (2017). Informal leadership status and individual performance: The roles of political skill and political will. Journal of Leadership and Organizational Studies, 24(1), 8394.

Smith, G. \& Saunders, J. (1990). The application of marketing to British politics. Journal of Marketing Management, 5(3), 307-323.

Sturman, M. C. (2003). Searching for the inverted Ushaped relationship between time and performance: Meta-analyses of the experience/performance tenure/performance and age/performance relationships. Journal of Management, 29(5), 609-640.

Treadway, D. C. (2012). Political will in organizations. In G. R. Ferris \& D. C. Treadway (Eds.), Politics in organizations: Theory and research considerations (pp. 531-556). New York, NY: Routledge/Taylor and Francis.
Treadway, D. C., Douglas, C., Ellen, B. P. III, Summers, J. K., \& Ferris, G. R. (2014). Leader political skill and team effectiveness: The positioning of political skill in the framework of leader competencies. In R. E. Riggio \& S. J. Tan (Eds.), Leader interpersonal and influence skills: The soft skills of leadership (173-206). New York, NY: Routledge.

Treadway, D. C., Ferris, G. R., Duke, A. B., Adams, G., \& Thatcher, J. B. (2007). The moderating role of subordinate political skill on supervisors' impressions of subordinate ingratiation and ratings of interpersonal facilitation. Journal of Applied Psychology, 92(3), 848-855.

Treadway, D. C., Hochwarter, W. A., Kacmar, C. J., \& Ferris, G. R. (2005). Political will, political skill, and political behavior. Journal of Organizational Behavior, 26(3), 229-245.

Van Velsor, E., \& Leslie, J. B. (1995). Why executives derail: Perspectives across time and cultures. Academy of Management Executive, 9(4), 62-72.

Van Wart, M. \& Dicke, L. A. (2007). Administrative leadership in the public sector. NY, USA: M. E. Sharpe.

Venkataramani, V., Richter, A. W., \& Clarke, R. (2014). Creative benefits from well connected leaders: Leader social network ties as facilitators of employee radical creativity. Journal of Applied Psychology, 99(5), 966-975.

Waldman, D. A. \& Avolio, B. J. (1986). A meta analysis of age differences in job performance. Journal of Applied Psychology, 71(1), 33-38.

Wring, D. (1997). Reconciling marketing with political science: Theories of political marketing. Journal of Marketing Management, 13(7), 651663.

Wu, L. Z., Kwan, H. K., Wei, L. Q., \& Liu, J. (2013). Ingratiation in the workplace: The role of subordinate and supervisor political skill. Journal of Management Studies, 50(6), 991-1017.

Zhang, Z., Waldman, D. A., \& Wang, Z. (2012). A multilevel investigation of leader member exchange informal leader emergence and individual and team performance. Personnel Psychology, 65(1), 49-78. 